\title{
DEBT SERVICING AND ECONOMIC GROWTH IN NIGERIA: AN EMPIRICAL INVESTIGATION
}

\author{
W. A. ADESOLA
}

(Received 30, January 2009; Revision Accepted 20, April 2009)

\begin{abstract}
In this study we reviewed and analyse the effect of external debt service payment practices on sustainable economic growth and development with particular emphasis on Nigeria. To achieve the objective of this research, we use debt payment to Multilateral Financial creditors, Paris club creditors, London club creditors, Promissory notes holders and other creditors (Non-Paris Creditors) as variables to statistically determine whether they have inverse relationship with gross domestic product (GDP) and gross fixed capital formation at current market prices (GFCF). Data pertaining to 1981 through 2004 were used with the ordinary least square multiple regression method. We found that debt payment to London club creditors, Paris club creditors, promissory notes holders and Other creditors have significant impact on the GDP and GFCF. Debt payment to Paris club creditors and debt payment to promissory notes holders are positively related to GDP and GFCF, while debt payment to London club creditors and Other creditors shows a negative significant relation to GDP and GFCF. We therefore recommend among others that government should ensure that any loan deal with either London club or Other creditors should be deal that will open Nigeria to greater trade and investment and can stimulate the private sector, since debt payment to these two creditors impact negatively on our economic growth.
\end{abstract}

KEYWORDS: Debt Management, Creditors, Debtors, Gross Domestic Product

\section{INTRODUCTION}

The origin of Nigeria's external debts dates back to 1958 when a sum of US $\$ 28$ million was contracted for railway construction. Between 1958 and 1977, the level of foreign debt was minimal, as debt contracted during the period were the confessionals debts from bilateral and multilateral sources with longer repayment periods and lower interest rates constituting about 78.5 percent of the total debt stock. From1978, following the collapse of oil prices, which exerted considerable pressure on government finances, it became necessary to borrow for balance of payments support and project financing. This led to the promulgation of Degree No 30 of 1978 limiting the external loans the federal government could raise to 5 billion Naira. The first major borrowing of US $\$ 1$ billion referred to as jumbo loan was contracted from the international capital market (ICM) in 1978 increasing the total debt to US $\$ 2.2$ billion. Thereafter, the spate of borrowing increased with the entry of state governments into external loan contractual obligations. While the share of loans from bilateral and multilateral sources decline substantially borrowing from private sources also increased considerably. Thus by 1982, the total external debt stock was US\$13.1 billion.

Nigeria's inability to settle her import bills resulted in the accumulation of trade arears amounting to US $\$ 9.8$ billion, between 1983 and 1988. The insured and uninsured components were US \$2.4 and US $\$ 7.4$ billion respectively. A reconciliation exercise which took place between 1983 and 1988 with London and Paris club reduced amount to US $\$ 3.8$ billion with an accrued interest of US $\$ 1.0$ billion bringing the total to US $\$ 4.8$ in 1998. The external debts rose further to US $\$ 33.1$ billion in1990 but decreased to US $\$ 27.5$ billion in 1991 and increased steadily to US $\$ 32.6$ billion at end of Dec. 1995.

The total debt outstanding at the end of 1999 was US $\$ 28.0$ billion with Paris club constituting the highest source with a share of 73.2 percent in 1999 prior to the canvass made for debt

W. A. Adesola, Department of Computer Science, Cross River University of Technology, Calabar 
cancellation. Contrary to the illusory- image of "oil-rich" country, Nigeria is a heartily indebted poor country. Its total external debt stock, as at December 2000, is estimated by the Nigerian government at about $\$ 28.3$ billion, it includes arrears amounting to $\$ 14.7$ billion and late interest of over $\$ 5$ billion. A significant proportion of thus debt $(75 \%)$ is owed to official creditors. The bulk of Nigeria's debt was incurred at non confessional terms during the late 1970s and early 1980 s, during a period of significantly low interest rate regime when the London inter Bank offered Rate (LIBOR) hovered between 3 and $4 \%$. The debt grew rapidly through the eighties due to accumulation of debt service arrears and escalation of market interest rate. LIBOR peaked at $13 \%$ in mid 1989. As a result, the pre-1984 debt of most developing countries, Nigeria inclusive quadrupled by 1990 . The collapse in oil price compounded by poor economic policies, bad management and unfavourable loan terms, made it externally difficult to service the mounting external debt obligation, particularly those due to the Paris club. Hence despite the rescheduling in 1986, 1989 and 1991 arrears continue to amount, which further worsened the debt problem. Some progress was made however in restricting the commercial debts, and Nigeria has continued to service that category of debt as at when due. The trend of the debts highlights the fact that much of the country's external debt is owed to fifteen creditor countries belonging to the Paris club, as a percentage of the total external debt, Nigeria's indebtedness to this group rose almost consistently from about $30 \%$ in 1983 to about $80 \%$ in 2001 . This huge external debt constitutes a major impediment to the revitalization of its shattered economy as well as the alleviation of debilitating poverty. As at December 2000, Nigeria's debt stock amounted to about 75 percent of GDP and about 180 percent of export earning. Debt service due in 2000 was about US $\$ 3.0$ billion or 14.5 percent export of export earnings. In 1999, for example spending on health represented about $0.2 \%$ of GDP and 0.7 percent of GDP compared with 3.4 percent (US $\$ 1.5$ billion) annual budget spent on debt servicing during the same period. In 2000, US $\$ 1.9$ billion was used for debt servicing translating to about 4 times federal Government budgetary allocation to education and about 12 times the allocation to health while in 2001 debt service payment was US $\$ 2.13$ billion which amounted to 6 times of the Federal Government's budgetary allocation to education and 17 times allocation to health for that year.
This problem can be better understood if the resources committed to debt services as listed above are related to national output. Thus, this research is necessary at this point, when new loans are being negotiated from China(see Ali and Mshelia) and other countries.

This research attempts to establish the relationship between poor economic growth and debt services in Nigeria. The broad aim of this paper is to examine the effect of external debt services on the Nigeria's Gross Domestic Product and Gross fixed Capital Formation. The specific objectives are to identify the sources of external debt (loans), to identify the creditors to Nigeria, to examine the genesis of Nigeria's external debt and to provide recommendations to the government.

\section{Research Hypotheses}

The following hypotheses are presented to be tested.

Hypothesis I

$\mathrm{H}_{0}$ : There is no significant relationship between gross fixed capital formation at current market prices and external debt services

$\mathrm{H}_{\mathrm{i}}$ : There is a significant relationship between gross fixed capital formation at current market prices and external debt services

\section{Hypothesis II}

$\mathrm{H}_{\mathrm{o}}$ : There is no significant relationship between gross domestic product at current market prices and external debt services.

$\mathrm{H}_{\mathrm{i}}$ : There is a significant relationship between gross domestic product at current market prices and external debt services

\section{REVIEW OF RELATED LITERATURE}

\subsection{Analysis of the Nigerian External Debt Policies and performance. \\ a. Pre- SAP period $1962-1985$ \\ The national economic development} planning started with expenditure of $€ 678.8$ fifty percent of which emanated from foreign sources either in form of foreign private investment or direct foreign assistance to government. The basic objective of planning in Nigeria is not merely to accelerate the rate of economic growth and the rate at which the standard of living of the population can be raised; it is also to give an increasing measure of control over its future. 
Nigeria has four different development plans before 1985. These are;

The first national Development Programme 1962 $-1968$

The second National Development Programme $1970-1974$

The Third National Development Programme $1975-1980$

The fourth National Development Programme $1980-1985$

The performance of the Nigeria economy during the first two decades after independence was generally impressive than in the Pre - in dependence period in spite of the atmosphere of tumultuous political resurgence. The average GDP growth rate was 5.1 percent during first National Development Plan, 8.2 percent under the second and 5.0 percent under the Third. In the same vein the growth rate of capital formation (investment ration) rose from an average of 14.1 percent under the first plan to 26.7 percent in the third plan.

\section{b. Structural adjustment program (SAP) period 1986-1991}

The Nigeria SAP was designed to fit the standard IMF - World Bank structural adjustment packages and meant to effectively alter and restructure the consumption and production patterns of the Nigerian economy, as well, to dominate price distortions and heavy dependence on the export of crude oil and imports of consumer and producer good (Anyanwu 1997). The programme was proposed as an economy package designed to rapidly and effectively transform the national economy over a period of less than two years (Yesufu, 1996).

According to Adeyemi (1996), the philosophy of SAP was predicted on demand management as a measure of curtailing external imbalance with a restrictive monetary policy. The ultimate objective was to achieve non- inflationary growth and to stimulate domestic production of tradable goods. In addition, SAP was to achieve a sustainable external debt service profile and hence, domestic savings and investment and the inflow of external resources.

The economic performance under the structural adjustment programme appears to have performed better in terms of sectoral and over all GDP growth rates. This is attributable to positive development in the agriculture, oil and financial sectors. The programme also corrected the over- valuation of the Naira which was a major cause of cheap import, enchanced the
Government revenue which consequently reduced the need to borrow.

However the external debt burden increased from US $\$ 19.5$ billion in 1985 to US $\$ 34.4$ billion in 1991 as a result of new borrowings, increased in foreign interest rate, capitalization of unpaid interest charges as well as the appreciation of exchange rates of various European and Japanese Currencies against US dollar. The debt service ratio which stood at an average of $16.3 \%$ between 1982- 1985 increased to 26.7 percent between 1986- 1994 creating a great strain on the foreign exchange earnings and reflecting the failure of the debt rescheduling programmes mapped out by the London and Paris club creditors (see Adepoju 2007).

The pains of SAP however, include endemic inflation, foreign exchange shortage, sharp increases in unemployment, deterioration in health and educational standard, low capacity utilization and ever - rising fiscal deficits (Anyanwu et al 1997). There was no efficiency in resources mobilization as saving refused to translate into investment (Adeyemi 1996).

\section{c. Post SAP period: 1997- 1998}

The external sector came under severe pressure in 1995 with the balance of payments recording further deficits. There was also further accumulation of debt service arrears, as the nation did not meets the obligations as at when due. Both the autonomous and parallel market exchange rates closed significantly averaging N82.3: US\$1 and N83.7: US\$1 respectively.

In 1997 there was downward pegging of allocation for debt serving since other options are being explored to solve the debt problem. This was to allow more foreign exchange to be made available for domestic used. It was generally agreed that the government should as a matter of policy not take any external loan except such are given on concessionary grounds and these should be used only for export- increasing or import- decreasing activities that can pay their ways back.

\section{d. Democratic period (1999- 2006)}

Nigeria External debt stock in 1999 remained at about the same level as it was in 1988- US $\$ 28.77$ billion. In spite of lifting of the embargo on foreign loans, no new loans were contracted. However, some categories of debt were not serviced; particularly those owed to the Paris club Creditor Country as well as arrears on post cut off date debt. In spite of the resources constraints, the sum of US $\$ 1.5$ billion was set 
apart to service external debt in year 2000 while arrangement continues on debt reduction negotiation with creditors.

The government resumed concessionary borrowing from multilateral and bilateral sources especially from the World Bank. Borrowed funds were strictly to be used for satisfactory social and infrastructural projects and export - increasing/ import - decreasing features (see Obadan 2000). The debt overhang of US $\$ 31.0$ billion in 2004 constitutes a deterrent to private investment and generally to growth and developing. The government in its budget proposed to service her external debt in a satisfactory manner without compromising the requirement for domestic growth. There is the strong need for Nigeria to seek substantial relief from the heavy debt burden through initiatives that have features of debt reduction. A serious implementation of the NEEDS reform programme may be helpful in this regard (Obadan 2004).

\subsubsection{Nigeria External Debt Creditors}

Nigeria has contacted a number of debt obligations from eternal source. This could be grouped into two main categories.

1. Official Debt: this consists of Paris club debt, multilateral debts and bilateral debts.

2. Private debts: this is made up of uninsured short- term trade arears contracted through the medium of bills for collection, open account, etc. commercial bank debts acquire through loans/letters of credit. Credits are in this case referred to London club debts.

a. Much of the Country's external debt is owed to fifteen creditor countries belonging to the Paris club. Paris club debt is government to government credits or market- based term loans, which are guaranteed by various export credit agencies of the creditor countries. The Paris club is a cartel of creditors' countries that provide an information forum where countries experiencing difficulties in paying their official debt meet with creditors to reschedule the debts. It is an informal group with no permanent members, which works under principle of consensus. Paris club members, who Nigeria is indebted, are: Australia, U.S.A, Spain, Israel, France Switzerland, Germany, Demark, Italy, the Netherlands, Japan, the U.K, Belgium, Russia and Finland. The total amount owed to members of the club as at Dec 312004 amounted to US $\$ 35.9$ billion.

b. The second category is the multilateral debts. These are projects loans owed to multilateral financial initiatives (e.g. the World Bank Group, the African Development Bank Group, the European Investment Bank Group, IFAD and ECOWAS Fund). By federal and state governments and their agencies. The total amount owed to multilateral institutions by Nigeria as at December 2004 was US $\$ 2.8$ billion.

c. The third categories of debts is bilateral debt otherwise called Non- Paris club bilateral debt. These are debt owed to countries which are not members of the Paris club but whose debts are not insured by the export credit agencies. the amount owed to this categories by Nigeria as at December 2004 was US0.05 billion. Debt service payment in 2001 and 2002 to them were US\$33.81 and US\$34.9 million.

d. The fourth categories of debts are the commercial debts. They are further divided into two groups.

i. London club: This is a group of commercial banks that join together to negotiate the restricting of their claims against debtor countries. London club debts are arrears of commercial bank term loans. They also include some arrears of letter of credit, bills for collection, open account, dividends, and airline remittances. The total amount owed by Nigeria as at December 2004 was US1.4 billion.

ii. Central Bank of Nigeria (CBN) promissory notes. These were trade arrears contracted by ordinary Nigerians, between 1981 and 1986 but who deposited the local currency with which to make the remittances. This is why the promissory notes $(\mathrm{PN})$ are now regarded as federal government of Nigeria's debt. The arrears were finally covered with promissory notes in January 1988, the stock amount to US $\$ 4.8$ billion to be authorized quarterly ending on January 5,2010 . The outstanding balance of PN as at December 31, 2004 was US $\$ 0.8$ billion. Annual debt service on promissory notes by Nigeria government was about US\$200 million as at December 2004. 
As at December 31, 2004, total external debt stock stood at US\$35 billion. The federal Government of Nigeria owed about US\$21.08 billion or $76.14 \%$ while the 36 states owed about US $\$ 7.265$ billion or $23.86 \%$.

\section{$2.2 \quad$ Empirical Literature}

There have been several attempts to empirically assess the external debt - economic growth link - the debt overhang and crowding out effects - mainly by using OLS. Borensztein (1990) found that debt overhang had an adverse effect on private investment in Philippines. The effect was strongest when private debt rather than total debt was used as a measure of the debt overhang. Iyoha (1996) observed similar results for SSA countries. He concluded that heavy debt burden acts to reduce investment through both the debt overhang and the 'crowding out' effect. Using data from Cameroon, Mbanga and Sikod (2001) found that there exist a debt overhang and crowding out effects on private and public investments respectively. Elbadawi et al (1996) confirmed a debt overhang effect on economic growth using cross- sectional regression for 99 developing countries spanning SSA, Latin America, Asia and Middle East. They identified three direct channels in which indebtedness in SSA works against growth: current debt inflows as ratio of GDP (which should stimulate growth), past debt accumulation (capturing debt overhang) and debt service ratio. The fourth indirect channels on public sector expenditure. Elbadawi, et al (1996) concluded that debt accumulation deters growth while debt stock spurs growth. Their result also showed that the debt burden has led to fiscal distress as manifested by severely compressed budgets.

Degefe (1992) also discovered a negative effect of external debt on growth. Fosu (1996) argued that debt can additionally influence economic growth via effect on the productivity of investment. And even if debt service payments do not reduce saving and investments significantly. They could still decrease output growth directly by diminishing productivity as a result of the adverse changes in investment mix. Ajayi (1991), Osei (1995) and Mbire \&Atingi (1997) used the simulation analysis to show the impact of the debt burden indicators on economic growth under different scenarios.

Furthermore, Elbadawi, et al (1996) opined that these debt burden indicators also affect growth indirectly through their impact on public sector expenditures. As economic condition worsens, government find themselves with fewer resources and public expenditure is cut. Part of this expenditure destined for social programs has several effects on the very poor. Most studies confirm debt overhang/ crowding out effects. The only work that has shown favourable effect of external debt is Chowdhurry (1994) for Bangladesh, Indonesia and South Korea.

Were (2001) using an error correction formulation, the estimation result showed a debt overhang problem in both the growth and investment equation. This result tally with result from similar studies (e.g. Elbadawi et al, 1996, Mbanga \& Sikod 2001). The estimation result for the growth equation showed that not only does past debt accumulation deters growth but so do current debt flow in the short run. The error correction term also showed that external debt had negative implications on growth.

Ali \& Mshelia(2007) using Nigerian debt data found among others; positive and negative relations with GDP.

\section{RESEARCH METHOLOGY}

\subsection{Sources of Data}

The data for this study were derived from various secondary sources such as: The Central Bank of Nigeria Statistical Bulletin (2006) Volume 17; the Federal Bureau of Statistical (formerly federal office of Statistics) Abstract of Statistics (various issues) and Central Bank of Nigeria website (www.cenbak.org). Debt data was extracted from debt Management office (DMO) publication and also from their website (www.dmo.org).

\subsection{Model Specification}

The following models were built in line with the hypotheses of the study.

$$
\begin{array}{ll}
\text { 1. } & \text { GDP }=\quad \beta_{0}+\beta_{1} L C+\beta_{2} \mathrm{MLC}+ \\
& \beta_{3} \mathrm{PC}+\beta_{4} \mathrm{PN}+\beta_{5} \mathrm{OTHERS}+\mu \mathrm{t} \\
& \\
& \mathrm{GFCF}=\quad \beta_{0}+\beta_{1} \mathrm{LC}+\beta_{2} \mathrm{MLC}+ \\
& \beta_{3} \mathrm{PC}+\beta_{4} \mathrm{PN}+\beta_{5} \mathrm{OTHERS}+\mu \mathrm{t}
\end{array}
$$

\section{Variables}

$\beta_{0,} \beta_{1}, \beta_{2}, \beta_{3}, \beta_{4}, \beta_{5}$ are regression parameters. $\mu$ is the error term.

GDP $=$ Gross domestic product at current market price.

GFCF = Gross fixed capital formation at current market price.

$\mathrm{LC}=$ Annual debt service payment to the London Club Creditors 
MFC = Annual debt service payment to Multilateral Financial Creditors.

$\mathrm{PC}=$ Annual debt service payment to the Paris club creditors

$\mathrm{PN}=$ Annual debt service payment to Promissory Note Holders.

OTHERS = Annual debt service payment to other creditors

\section{Limitation of study}

One of the limitations of this study is the use of annual data rather than quarterly data. Whereas quarterly data or even monthly data are available for some of the variables used, others are only available in annual form. Furthermore, a major limitation of this study is the methodological constraint; given the current development in theoretical econometrics. It is therefore suggested that the use of more robust system estimation technique be attempted in future to seek the establishment of a bidirectional cause and effect relationship among the variables.

\section{EMPIRICAL RESULTS AND ANALYSIS}

\subsection{Data Presentation}

Data were presented here to help in the test of the hypotheses later in the study. These data were to aid the discovery of the impact of debt servicing on the economic growth of Nigeria.

Table 4.1: The relationship between gross domestic product (GDP) and Nigeria external debt servicing

$\begin{array}{lllllll}\text { Years } & \text { GDP } & \text { Multilateral } & \begin{array}{l}\text { by category } \\ \text { Paris } \\ \text { Club }\end{array} & \begin{array}{l}\text { London } \\ \text { Club }\end{array} & \begin{array}{l}\text { Promissory } \\ \text { Note }\end{array} & \text { Others } \\ & & & & & & \\ 1981 & 102686.8 & 179.6 & 1975.9 & & & \\ 1982 & 110029.8 & 530.4 & 5474.4 & 1981.7 & & 832.9 \\ 1983 & 119117.1 & 566.4 & 6002.2 & 2758.8 & & 701.4 \\ 1984 & 125074.8 & 1271.2 & 6360.4 & 5443.7 & 548.9 & 578.3 \\ 1985 & 144724.1 & 1293.5 & 7726.4 & 6164.3 & 1155.1 & 842.5 \\ 1986 & 143623.9 & 4670.7 & 21725.3 & 8444.7 & 1273.9 & 2459.1 \\ 1987 & 203037.1 & 8781.5 & 63205.6 & 6766.5 & 4152.6 & 1400.8 \\ 1988 & 275198.2 & 9991.8 & 75445.3 & 14986.1 & 20634.7 & 7791.0 \\ 1989 & 403762.9 & 21473.6 & 121229.6 & 42840.0 & 25742.1 & 19782.9 \\ 1990 & 497351.3 & 34606.3 & 154550.6 & 53431.8 & 35067.6 & 15075.2 \\ 1991 & 574282.1 & 39458.3 & 173051.2 & 58238.1 & 40950.5 & 14144.3 \\ 1992 & 909754.2 & 89274.3 & 324729.9 & 41890.6 & 43561.9 & 24229.3 \\ 1993 & 1132181.2 & 81456.3 & 400380.9 & 45323.8 & 64140.0 & 36317.7 \\ 1994 & 145129.7 & 97056.6 & 404212.6 & 45367.9 & 69665.7 & 32106.8 \\ 1995 & 2991941.7 & 97042.0 & 476731.2 & 44990.0 & 70069.1 & 28846.4 \\ 1996 & 4135813.6 & 102630.0 & 420002.0 & 44946.0 & 69256.0 & 2662.0 \\ 1997 & 4300209.0 & 96199.0 & 417568.8 & 44946.0 & 47080.0 & 1742.2 \\ 1998 & 4101028.3 & 93214.0 & 458257.8 & 44946.0 & 35475.9 & 1447.6 \\ 1999 & 4799966.0 & 361194.9 & 1885664.8 & 187627.1 & 35151.6 & 6363.8 \\ 2000 & 6850228.8 & 379043.0 & 2320269.0 & 223832.6 & 36523.8 & 15753.3 \\ 2001 & 7055331.0 & 313504.7 & 2475509.4 & 228950.2 & 158486.0 & 13580.5 \\ 2002 & 7984385.3 & 375700.1 & 3220823.5 & 182964.5 & 144746.2 & 7055.6 \\ 2003 & 10136364.0 & 413877.7 & 3737279.9 & 196156.9 & 123994.6 & 702.2 \\ 2004 & 11673602.2 & 384248.7 & 4196844.6 & 196155.5 & 106558.4 & 6462.4\end{array}$

Source: CBN Statistical Bulletin (2006), DMO publications, National Bureau of Statistics (NBS) 
Table 4.2: The relationship between gross fixed capital formation (GFCF) and Nigeria external debt servicing to creditors by category

$\begin{array}{lllllll}\text { Years } & \text { GFCF } & \text { Multilateral } & \begin{array}{l}\text { Paris } \\ \text { Club }\end{array} & \begin{array}{l}\text { London } \\ \text { Club }\end{array} & \begin{array}{l}\text { Promissory } \\ \text { Note }\end{array} & \text { Others } \\ & & & & & & \\ 1981 & 12215.0 & 179.6 & 1975.9 & - & - & 175.7 \\ 1982 & 10922.0 & 530.4 & 5474.4 & 1981.7 & - & 832.9 \\ 1983 & 8135.0 & 566.4 & 6002.2 & 2758.8 & - & 701.4 \\ 1984 & 5417 & 1271.2 & 6360.4 & 5443.7 & 548.9 & 578.3 \\ 1985 & 5573.0 & 1293.5 & 7726.4 & 6164.3 & 1155.1 & 842.5 \\ 1986 & 7323.0 & 4670.7 & 21725.3 & 8444.7 & 1273.9 & 2459.1 \\ 1987 & 10661.1 & 8781.5 & 63205.6 & 6766.5 & 4152.6 & 1400.8 \\ 1988 & 12383.7 & 9991.8 & 75445.3 & 14986.1 & 20634.7 & 7791.0 \\ 1989 & 18414.1 & 21473.6 & 121229.6 & 42840.0 & 25742.1 & 19782.9 \\ 1990 & 30626.8 & 34606.3 & 154550.6 & 53431.8 & 35067.6 & 15075.2 \\ 1991 & 35423.9 & 39458.3 & 173051.2 & 58238.1 & 40950.5 & 14144.3 \\ 1992 & 58640.3 & 89274.3 & 324729.9 & 41890.6 & 43561.9 & 24229.3 \\ 1993 & 80948.1 & 81456.3 & 400380.9 & 45323.8 & 64140.0 & 36317.7 \\ 1994 & 85021.9 & 97056.6 & 404212.6 & 45367.9 & 69665.7 & 32106.8 \\ 1995 & 114476.3 & 97042.0 & 476731.2 & 44990.0 & 70069.1 & 28846.4 \\ 1996 & 172105.7 & 102630.0 & 420002.0 & 44946.0 & 69256.0 & 2662.0 \\ 1997 & 205553.2 & 96199.0 & 417568.8 & 44946.0 & 47080.0 & 1742.2 \\ 1998 & 192984.4 & 93214.0 & 458257.8 & 44946.0 & 35475.9 & 1447.6 \\ 1999 & 175735.8 & 361194.9 & 1885664.8 & 187627.1 & 35151.6 & 6363.8 \\ 2000 & 268894.5 & 379043.0 & 2320269.0 & 223832.6 & 36523.8 & 15753.3 \\ 2001 & 371897.9 & 313504.7 & 2475509.4 & 228950.2 & 158486.0 & 13580.5 \\ 2002 & 438114.9 & 375700.1 & 3220823.5 & 182964.5 & 144746.2 & 7055.6 \\ 2003 & 429230.0 & 413877.7 & 3737279.9 & 196156.9 & 123994.6 & 702.2 \\ 2004 & 11673602.2 & 384248.7 & 4196844.6 & 196155.5 & 106558.4 & 6462.4\end{array}$

Source: CBN Statistical Bulletin (2006), DMO publications, National Bureau of Statistics (NBS)

\subsection{Data Analysis}

In this section, we carry out the analysis of the estimated results. The analysis is done on equation basis,

\section{Equation 4.1}

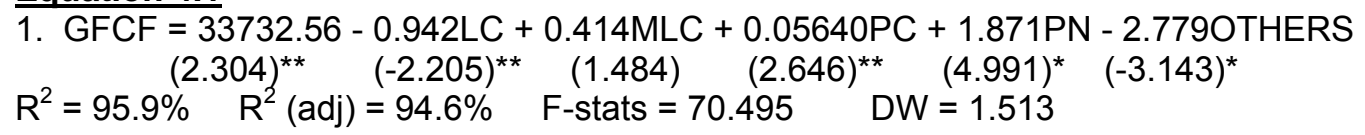

\section{Equation 4.2}
2. GDP $=849699.4-20.925 L C+12.3$
12.397MLC +
1.511PC + 25.216PN - 52.3200THERS
$\mathrm{R}^{2}=94.5 \%$$$
(2.183)^{* *}(-1.842)^{* * *}
$$
$(2.666)^{* *}(42.530)^{* *}$
$(-2.227)^{\star *}$

The numbers in bracket represent $t-$ value, while the number directly beneath the bracket represents the parameter estimates. *indicate that the estimated co-efficient is statistically significant at $1 \%$ level of significance, ${ }^{* *}$ indicate that the estimated co-efficient is statistically significant at 5 per cent level of significance while $* * *$ indicate that the estimated co-efficient is statistically significant at 10 per cent level of significance.

In equation 4.1: Gross fixed capital formation (GFCF) equation shows a high explanatory power of the independent variables. The coefficient of multiple determination $\left(R^{2}\right)$ of 0.959 or $95.9 \%$ indicates that about $95.9 \%$ variations in the observed behaviour in the dependent 
variables is jointly explained by the independent variables. The remaining $4.1 \%$ may better be accounted for by the other omitted variables and is represented by the stochastic error term. The high $\mathrm{R}^{2}$ indicates that the model fits the data well and is statistically robust; there is a tight fit of the model. The F-statistic of 70.495 is significant at $1 \%$ level considering the table F-statistic $\left[F_{0.01}(5,18)=4.25\right]$. F-test is the overall or joint significant test of the parameters in the model. The calculated F-statistic is greater than the table F-statistic (i.e. $70.495>4.25$ ), therefore it is significant at $1 \%$ level. This buttress the fact that the high $\mathrm{R}^{2}$ is better than would have occurred by chance. On the test of significance, the table tstatistic, two-tailed test, with degree of freedom, $\mathrm{N}-\mathrm{K}=24-6=18$, the following correspond to $1 \%$. $5 \%$ and $10 \%$ significance levels respectively: $2.878,2.101$, and 1.734 . Any parameter that is less than the above figures (the least being the $10 \%$ level)is statistically insignificant in the model; and therefore, could as well be removed from the model and the overall goodness of fit $\left(R^{2}\right)$ may not be significantly affected as stated in koutsoyannis (1997). A cursory look at the model shows that only the debt payment to multilateral financial creditors (MFC) parameter fail the test of significance. The rest being significant at better than $10 \%$ level of significance. Debt payment to Paris club creditor (PC) and debt payment to promissory note holders(PN) carried the wrong sign. This means that if there is a one percent increase or decrease in debt payment to PC and $\mathrm{PN}$, gross fixed capital formulation will increase or reduce by 0.05640 and 1.871 respectively. Another essential test is the second order or econometric criteria: the DW statistic is 1.101. The table DW at $5 \%$ level indicates the following: given $\mathrm{K} 1=5$ (excluding the constant term) and sample size $(n)$ equals 24 : then $d l=0.925$. $d u=$ 1.902, $4-\mathrm{du}=2.098$ and $4-\mathrm{dl}=3.075$. our estimated DW statistic (1.101) shows an inconclusive result about the presence or absence of serial correlation.

In Equation 4.2: The equation of gross domestic product (GDP) shows a high explanatory power of the independent variables. The coefficient of multiple determination $\left(R^{2}\right)$ of 0.945 or $94.5 \%$ indicates that about $94.5 \%$ variation in the observed behaviour in the dependent variable is jointly explained by the independent variables. The remaining $5.5 \%$ may better be accounted for by other omitted variables and is represented by the stochastic error term. The high $\mathrm{R}^{2}$ indicates that the model fits the data well and is statistically robust; there is a tight fit of the model. The Fstatistic of 51.612 is significant at $1 \%$ level considering the table F-Statistic $\left[\mathrm{F}_{0.01}(5,18)=\right.$ 4.25]. The calculated F-statistic is greater than the table F-statistics $(51.612>4.25)$, therefore it is significant at $1 \%$ level. On the test of significance, only debt payment to multilateral financial creditors (MFC) failed the test of significance. Under economic a prior criteria the positive sign of the estimated coefficient of PC and $\mathrm{PN}$ are inconsistent with the economic a priors expectation. That debt payment should have a negative effect on economic growth. This means that if there is a one percent increase or decrease in debt payment to Paris club creditors(PC) and promissory note holders(PN), gross domestic product will increase or reduce by 1.1511 and 25.216 respectively. The magnitude of the negative effect of the debt payment to creditors in order of importance to economic growth is as follows: OTHERS (-52.320) and LC $(-20.925)$ respectively. The DW statistic is 1.513 shows an inconclusive result about the presence or absence of serial correlation.

\subsection{Test of Hypotheses}

The researcher earlier identified two hypotheses which will be tested at $1 \%$ level of significance.

\section{Hypothesis I}

$\mathrm{H}_{0}$ : There is no significant relationship between gross fixed capital formation at current market prices and external debt services

$\mathrm{H}_{\mathrm{i}}$ : There is a significant relationship between gross fixed capital formation at current market prices and external debt services

The tabulated value of the F Statistics i.e. F stats $(5,18)$ is 4.25 .

The decision rule for the test of hypothesis is : Accept $\mathrm{H}_{\mathrm{o}}$ if Calculated $\mathrm{F}$ _ratio $(5,18) \leq 4.25$

Reject $\mathrm{H}_{\mathrm{o}}$ if Calculated $\mathrm{F}_{\text {ratio }}(5,18)>4.25$

Therefore, $70.495>4.25$, so we reject $\mathrm{H}_{\mathrm{o}}$ and accept $\mathrm{H}_{1}$

There is a significant relationship between gross fixed capital formation at current market prices and external debt services.

\section{Hypothesis II}

$\mathrm{H}_{0}$ : There is no significant relationship between gross domestic product at current market prices and external debt services. 
$\mathrm{H}_{\mathrm{i}}$ : $\quad$ There is a significant relationship between gross domestic product at current market prices and external debt services.

The tabulated value of the F Statistics i.e. F stats $(5,18)$ is 4.25 .

The decision rule for the test of hypothesis is: Accept $\mathrm{H}_{\mathrm{o}}$ if Calculated $\mathrm{F}$ ratio $(5,18) \leq 4.25$

Reject $\mathrm{H}_{\mathrm{o}}$ if Calculated $\mathrm{F}$ ratio $(5,18)>4.25$

Therefore, $51.617>4.25$, so we reject $\mathrm{H}_{\mathrm{o}}$ and accept $\mathrm{H}_{1}$

There is a significant relationship between gross domestic product at current market prices and external debt services.

\subsection{Discussion of Findings}

Our study shows that debt payment to Nigerian creditors affect the economic growth both positively and negatively. This is partially consistent with the work of $\mathrm{ALI}$ and Mshelia (2007) who found a mixed outcome; the influence of the value of intercept and debt service payment to Paris club creditor (PC) and promissory note holders(PN) showed some level of positive relationship while debt payment to London club of creditors(LC) and Other creditors(OTHERS) indicated a negative relationship with both GFCF and GDP; but with difference in parameters sign in both study. In their study they found MLC and PN to be positively significant while LC and OTHERS are negatively significant.

The main findings of this study are

1. That economic growth in Nigeria are significantly influenced by debt payment to other creditors, Paris club creditors, London club creditors and promissory note holders except payment to Multilateral Financial creditors has no significant influence.

2. That debt payment to other creditors and London club creditors are significant and negatively influence the observed economic growth as (proxied by both) gross domestic and gross fixed capital formation.

3. That debt payment to Paris club creditors (PC) and promissory note holders are significant and positively influence the observed Nigerian economic growth.

4. That the magnitude of the negative impact of the debt payment to Other creditors(OTHERS) is greater than that of the London Club creditors(LC) suggest that the main determinant of our economic growth is the debt servicing payment to Other creditors.

\section{CONCLUDING REMARKS}

Empirical analysis of the impact of debt payment to creditors on the economic growth of Nigeria was the focus of this study. As earlier discussed, Nigeria is indebted to several creditors and this does not augur well for the overall well being of our economy.

In other to achieve the objective of this work; twenty four year period of debt payment to creditors were considered between 1981 through 2004. This is because we believe that twenty four years is long enough to smoothen fluctuations in the data collected: five main creditors were considered: they include Paris club creditors, multilateral financial creditors, London club creditors, promissory note holders and other creditors not belonging to any of the four creditors earlier listed. The data collected were used to generate the regression result to reflect the cause and effect relationship between the dependent and the independent variables on which this study is based.

The empirical result indicates among others:

i. That their exist a statistically significant relationship between gross fixed capital formation and debt payment to creditors.

ii. External debt services have a statistically significant impact on the economic growth(GDP) of Nigeria.

Based on our findings in this study, we wish to recommend the followings:

i. Government should provide enabling social and economic environment as this will encourage entrepreneurship and promote foreign direct investment.

ii. Government should promote portfolio investment which will generate employment opportunities that are highly needed for increase in per capital saving leading to high capital labour ratio.

iii. Place embargo on new loans especially to the state government and other government parastatals except for important economic reasons which are inevitable and for project which are self floating and self sustaining.

iv. Government should ensure that any deal with the London Club and Other creditors(i.e. Non Paris Club) should be deals that will open Nigeria to greater trade and investment and can stimulate the private sector since; debt services to 
these two creditors has a significant negative impact on our economic growth.

V. External financing of project should be used only for projects with higher priority. Thus is so because it is huge external debt that threw us into the series of economic problem in the first instance.

\section{REFERENCES}

Adepoju, A.A, Salau, A.S and Obayelu, A. E., 2007. The effect of External Debt Management on Sustainable Economic Growth and Development: Lessons from Nigeria, MPRA paper No.2147.

Adeyemi, F., 1996. Nigeria's External debt, Obafemi Awolowo University, press Itd ILE- Ife Nigeria pg 23

Ajayi, S. I., 1991. 'Macroeconomic approach to external debt: the case of Nigeria' Nairobi AERC (African economics research consortium), research paper 8.

Ali, B.M and Mshelia, S.I., 2007. Impact of external debt services on Nigeria's Economy, global journal of social sciences, 6, (2): pg. 111-118.

Anyanwu, J. C., 1997."Nigerian Public Finance", Joanee Educational Publishers Ltd, Onitsha, $1^{\text {st }}$ Ed. pp. 210.

Anyanwu J.C, Oyefusi, Oaikhenan and Dimowo, F.A, 1997. The structure of the Nigeria economy. Joanee Educational Published Itd, Onitsha, Anarmbra. Pg 631

Borensztein, E., 1990. 'Debt overhang, debt reduction and investment. The case of the Philippines". International monetary fund working paper No WP/90/77, September.

Crowdhurry, K. A., 1994. 'Structural analysis of external debt and economic growth: some evidence from selected countries in Asia and pacific.' Applied Economics 26.

Degefe, B., 1992. 'Growth and foreign debt: the Ethiopian experience: 1964- 86' Nairobi AERC Research paper 13.
Elbadawi, A. I., Ndulu, J. B. and Ndung'u, 1996. 'Debt overhang and economic growth in sub Saharan Africa' A paper presented to the IMF/World Bank Conference on external financing for low income countries December.

Fosu, A. K., 1996. 'The impact of external debt on economic growth in sub Saharan Africa'. Journal of economic development, 12. (1):

Iyoha, M. A., 1996. "External debt and Economic growth in Sub-Saharan African Countries: An Econometrics Study", A paper presented at AERC workshop, Nairobi.

Mbanga, G.N. and Sikod, F., 2001. "The impact of debt and debt-service payments on investment in Cameroon". A final report presented at AERC Biannual Research Workshop at the Grand Regency Hotel, Nairobi, May, 26-31.

Mbire, B. and Atingi, M.,1997. "Growth and Foreign Debt: The Ugandan Experience.". AERC Research Paper 66, Nairobi.

Obadan, M.I., 2000. External Sector Policy". Bullion a Publication of the CBN 24, (2): pp $39-43$.

Obadan M.I., 2004. External Sector Policy. Bullion CBN publication, 28: Pg 30-40.

Osei, B., 1995. "Ghana: The burden of debt service payment under structural Adjustment". AERC research paper 33: Nairobi.

Were, M., 2001. "The impact of external debt on economic growth and private investments in Kenya: An Empirical Assessment". A paper presented at the Wider development conference on debt relief, August, $17-18$.

Yesufu T. M., 1996. The Nigerian Economy: Growth without Development Benin Social Series for Africa. University of Benin, Benin city, Pg $89-110$. 


\section{APPENDIX A: REGRESSION RESULTS}

Table A: Standard Multiple Regression Result for equation 4.1

$\begin{array}{lccr}\text { Regressor } & \text { Coefficient } & \text { Standard Error } & \text { t-ratio } \\ \text { (Constant) } & 849699.4 & 389175.9 & 2.183 \\ \text { LC } & -20.925 & 11.358 & -1.842 \\ \text { MLC } & 12.397 & 7.410 & 1.673 \\ \text { OTHERS } & -52.320 & 23.498 & -2.227 \\ \text { PC } & 1.511 & 0.567 & 2.666 \\ \text { PN } & 25.216 & 9.965 & 2.530\end{array}$

Dependent Variable: GDP

R_Square $=0.945$

Adj. R_Square $=0.927$

SER $=968997.6$

F_statistics $=51.612$

DW-Statistics $=1.101$

Source: Research results compiled from the secondary data.

Table B: Standard Multiple Regression Result for equation 4.2

$\begin{array}{lccc}\text { Regressor } & \text { Coefficient } & \text { Standard Error } & \text { t-ratio } \\ \text { (Constant) } & 33732.56 & 14641.86 & 2.304 \\ \text { LC } & -0.942 & 0.427 & -2.205 \\ \text { MLC } & 0.414 & 0.279 & 1.484 \\ \text { OTHERS } & -2.779 & 0.884 & -3.143 \\ \text { PC } & 5.640 \mathrm{E}-02 & 0.021 & 2.646 \\ \text { PN } & 1.871 & 0.375 & 4.991\end{array}$

Dependent Variable: GCFC

$R \_$Square $=0.959 \quad$ Adj. R_Square $=0.946$ SER $=36456.34$

F- statistics $=70.495$

DW-Statistics $=1.513$

Source: Research results compiled from the secondary data. 